\title{
Muslim-Dominant
}

\section{From Dialogue to Living Together}

The Discussions on Inter-Religious Dialogue in Turkey since the Late 1990 s

\author{
Ayşe Zişan Furat \\ Associate Professor, Department of Religious Education, Faculty of \\ Theology, Istanbul University, Istanbul, Turkey \\ zisanfurat@istanbul.edu.tr \\ Hamit Er \\ Professor, Department of Religious Education, Faculty of Theology, Istanbul \\ University, Istanbul, Turkey \\ hamit.er@istanbul.edu.tr
}

\begin{abstract}
Interreligious dialogue (IRD) has been one of the vehemently debated topics in Turkey since the late gos. Many socio-political factors played a significant role in the proliferation of IRD discussions within the academic circles in this period. The multifaceted and complex nature of the term also attracted a wide audience outside the academia, and particularly, politically motivated organisations. Correspondingly, the term became one of the reference points for their propaganda goals.

Facing the complexity of the issue, this paper aims to disclose the evolution of IRD in Turkey by seeking answers to the question "how has the term IRD been perceived by Turkish scholars?" by providing insights about the major milestones in the discussions. The article concludes with an analysis of the main trends in the related discussions as follows: IRD as (1) a necessity for social welfare, (2) an instrument for religious propaganda, (3) and as part of dialogic relation.
\end{abstract}




\section{Keywords}

interreligious dialogue in Turkey - religion in Turkey - religion and state multiculturality

\section{Introduction}

Interreligious dialogue became one of the intensely debated topics in Turkey during the late 199os. Many factors played a significant role in its proliferation. Among them, political developments, societal changes, technological advancements, and the effects of globalization were frequently addressed by the relevant literature. Emergence of dissertations ${ }^{1}$ which scrutinized the topic from different aspects, including theology and religious studies as well as political studies eventually led the way to more systematic works comprising even discussions on the possibility of an authentic interreligious dialogue theory in Islam. However, it was the EU accession negotiations, which brought a certain momentum to the discussions. The emphasis in the negotiations on political and societal opening not only triggered an extensive administrative transition, but also encouraged an increase in social interactions with European countries. Furthermore, the multifaceted and complex nature of the term attracted a wide audience outside the academia, particularly politically motivated organizations.

The closeness to politics and policy developments has become both an advantage and a disadvantage for the evolution of the term in the Turkish context. While its conformity to contemporary discourses enabled the discussions to reach a wide audience, it also turned the term into an effective propaganda tool for religious groups advocating the most provocative interpretations of Islam, effectively placing the term under heavy criticism. This dualistic nature also created a certain ambiguity in terms of the conceptual and methodological framework of the term for researchers.

Since the politically motivated discussions regarding the issue have dominated the academic domain for a long time, a similar challenge has also arisen in the process of writing this paper. Against this background, the authors of this paper have chosen to restrict their analyses exclusively on the discursive construction of the concept of interreligious dialogue in the Turkish scholarly milieu as well as in official statements. They will refer to examples outside the

1 E.g., see Alıcı, Kitab-ı Mukaddes ve Kur'an-ı Kerim; Yiğitoğlu, Türkiye'de II. Vatikan Sonrası Müslüman-Hristiyan İlişkileri; Battal, Türkiye'deki Dinlerarası Diyalog Çalışmaları. 
academic circles only when it is regarded necessary to understand the scholarly discussions. The current paper aims to delve into the evolution of IRD discussions in Turkey by embracing a systematic approach as much as possible in an effort to provide useful insights into the milestones in the discussions. Acknowledging the fact that presenting the discussions chronologically is required if one is to present the full picture, a short analysis on the main trends is also added in the conclusion chapter of the paper.

\section{$2 \quad$ First Initiatives}

Modern Turkey is characterized by a high degree of cultural and religious diversity as a result of the cultural, and demographical texture it inherited from the Ottoman State. Its geographical location between the East and the West also signifies a state of cultural in-between which refers to at least two cultural zones while supporting its multicultural composition. Affirmative relations between the different religious groups which co-habited for centuries have developed a certain historical and cultural richness of which influence can be observed among their contemporary descendants. ${ }^{2}$ According to the latest census conducted in 2018, however, Turkey's population is approx. 82 million people. Although the official data does not provide any estimation as to the distribution of the population per religious affiliation, related demographic studies indicate that a very high percentage (of more than 95\%) of the population is Muslim, distributed among different denominations. ${ }^{3}$ The fact that non-Muslims make up but a fraction of the entire Turkish population seems to not have much of an impact on the slow but steady rise in the popularity of the term interreligious dialogue. On the contrary, the term had appeared in Turkish academic periodicals as early as the first initiatives on Muslim-Christian dialogue after the Second Vatican Council.

The Seminar on Dialogue between Islam and Christianity, organized by the Libyan Arab Republic in cooperation with the Holy See between February 1-6, 1976 was among the first comprehensive initiatives for Christian-Muslim dialogue, in which the Presidency of Religious Affairs [PRA] attended the seminar as an observer. Yet, the publication of an extensive report on the seminar by one of the Turkish representatives bespoke that a certain importance was

2 Anık, Çokkültürcülükve Osmanlı Devleti, p. 119.

3 Swiss Metadatabase of Religious Affiliation in Europe / SMRE: Countries and Regions: Turkey. Lucerne 2018. 
attached to the organization. ${ }^{4}$ Even as an observer, the very presence of the PRA at the meeting signalled that IRD was in the process of becoming part of the Turkish religious agenda, especially considering that the PRA was designed as the main constitutional body with official responsibilities for overseeing Muslim religious affairs, enlightening the population on religious matters and running the praying places in Turkey.

The opening speeches of the seminar showed that the underlying motive behind the organization was an array of long-term problems, inter alia the rise in conflicts, racism, nuclear weapons proliferation, among others, which both religions endured, but also the increasing threats originating from communism and moral corruption. Hence, the majority of the presentations concentrated on the social aspects of religion, even proposing solutions aimed at eliminating the above-mentioned problems and restoring peace and welfare for anyone in need.

Although the seminar was held in order to deliberate on the possible common undertakings of different religions, the minutes of the seminar showed that purely theological issues such as divine justice and the status of the other were inevitably also brought to the table. On the other hand, the concerns of organizers and Muslim participants on the possibility of contributing to misunderstandings regarding the status of Islam - the last and truest religion were also apparent in the text, given that the author included the then Libyan president Kaddafi's sermon on Islam as being "the true social religion" along with some articles on the supremacy of Islam over the other religions. ${ }^{5}$

Having attended the Libya meeting in observer capacity, in the late 199os the Presidency of Religious Affairs proactively decided to incorporate interreligious dialogue into its agenda. After some years of being cautions in formulating an official policy on IRD, the term was addressed for the first time in the First Council of Religion in 1993. The Council of Religion - one of the most comprehensive official meetings of the PRA - was designed as a body responsible for coming up with proposals on improving the quality of the religious services offered by the PRA. Therefore, the final decisions of the Council are of significance not only because of the fact that they reflect the PRA's contemporary agenda, but also because they reveal its official attitude. IRD was mentioned

4 Aydın, İslâm-Hristiyan Diyaloğu ve İslâmın Zaferi.

5 Aydın, İslâm-Hristiyan Diyaloğu ve İslâmın Zaferi, pp. 178-188; pp. 245-247, etc. 
among the recommendations to prospective religious functionaries in the 11th article of the 1993 Council's final decisions. The article reads as follows:

the persons who perform the duty of irshad [religious guidance] and the Presidency of Religious Affairs, which oversees this duty, should have a more active organization; it should be open to the outside world, it should make contacts and engage in dialogue with different service groups, denominations and religions. ${ }^{6}$

The content of the article indicated that the term was addressed within the framework of religious guidance services. It was considered as an effective instrument with the potential to consolidate the religious guidance services offered by the PRA. Such a formulation also reflected the main approach of the PRA towards IRD in the early stages, although in the following years this approach was somewhat expanded.

The First Eurasian Islamic Council, held in 1995, for example, associated the term with the misrepresentation of Islam in the West and also with the concerns regarding the misuse of IRD activities for the purpose of disseminating the religious message of certain groups. Therefore, IRD was portrayed as an efficient tool for explaining the true nature of Islam. The final declaration of the Council underlined two interrelated matters. First, Islam, as the final religion, promotes love, tolerance and peace as other divine religions. Therefore, depicting Islam as a terror religion is an insubstantial claim. Second, PRA acknowledges the right and freedom of other religions for conveying its message to people; however, it condemns the groups and their activities which exploit the socio-economical insufficiencies for their own good. ${ }^{7}$

The trend continued in the next Eurasian Islam Councils, which attached particular importance to the first point. Following the same approach, the $4^{\text {th }}$ and $5^{\text {th }}$ Eurasian Islam Councils, ${ }^{8}$ coinciding with the rise in violence in the Middle East and the 9/11 terror attack, embraced IRD as a point of paramount importance in promoting peace and tolerance and in finding solutions to common problems and warned against arbitrarily associating religions with terror acts.

6 Diyanet İşleri Başkanlığı [PRA], I. Din Şûrası Kararları, p. 70o, §11 (translation by the authors).

7 PRA, I. Avrasya İslâm Şûrası Teşkilatı Toplantısı Sonuç Bildirisi; PRA, II. Avrasya İslâm Şûrası Teşkilatı Toplantısı Sonuç Bildirisi.

8 PRA, IV. Avrasya İslâm Şûrası Teşkilatı Toplantısı Sonuç Bildirisi; PRA, v. Avrasya İslâm Şûrası Teşkilatı Toplantısı Sonuç Bildirisi. 
Referring to both the misrepresentation of Islam and the stepped-up missionary activities in Turkey, the Council's decisions indicated that the PRA's approach to IRD was shaped in accordance with the contemporary national and international developments. Moreover, it was oscillating between the advantages and disadvantages of IRD. In order to bring some clarification to this ambiguity, the Higher Commission of Religious Affairs in the PRA revealed its decision regarding IRD on March 13, 1997. The Commission's conclusions indicated that IRD was seen as an opportunity for the PRA to explain the real nature of Islam by reaching out to the non-Muslim world. ${ }^{9}$ Evidently, the IRD approach of the PRA was becoming more pragmatic.

Parallel with the growing interest in IRD, the Second Council of Religion in $1998,{ }^{10}$ attended by the leaders of different religious communities in Turkey, dedicated a full session to the subject matter. The discussions during the Council somewhat elucidated the term. Nevertheless, this iteration of the Council is considered as a milestone in the IRD discussions in Turkey not because of the extent and intensity of its deliberations, rather because of the fact that it outlined the main theoretical and methodological framework for the PRA's official approach on IRD and created a certain momentum for its future initiatives. In this regard, Prof. Dr. Mehmet Nuri Yllmaz, ${ }^{11}$ President of PRA at the time, argued that the main motive behind the inclusion of the topic into the Council's agenda was the need to contribute to world peace by developing a mutual understanding of coexistence. That could only be achieved through obtaining information about the other and appreciating the differences between and within the religions as something that enriches human beings. In line with the President, the official statement of the PRA also defined IRD as a humane and moral act which aims to enable people to live together despite their differences and avoid the pain and suffering they endure. ${ }^{12}$ Consequently, the discussions in the Council emphasized that relations between Christians and Muslims are what helps achieve successful coexistence rather than theological aspects and differences. ${ }^{13}$ However, the decisions of the Council, briefly but firmly, called attention to the other side of the coin as did previous councils: the link between interreligious dialogue and religious propaganda.

\footnotetext{
9 Uçar, Dinler Arası Diyalog Çıkmazı, p. 55.

10 PRA, II. Din Şûrası Tebliğ ve Müzakereleri.

11 Yllmaz, Diyanet Işleri, p. 768.

12 Gölcük, Dinler Arası Diyalogla İlgili, p. 5 .

13 Aydın, Müslüman-Hıristiyan Diyaloğunun Geleceği, pp. 96-105; Küçük, Dinler Arası Diyaloğa Niçin İhtiyaç Vardır, pp. 158-173; Sarıkçıŏ̆lu, İbrahim Dinine Güncel Yaklaşım, pp. 137-142; Uludağ, Sosyal Barışı Sağlamada Dinin ve Din Adamının Rolü, pp. 151-157.
} 
The tension generated by the question of "can interreligious dialogue be considered an effective tool for conveying the religious message, and as a result would it be in the form of religious guidance and/or a mission?" had already marked almost all discussion forums ever since the term entered into the academic terminology. Including a pertinent warning against the missionary activities in the final decisions of the Second Council of Religion signalled that this tension was to retain its importance in the upcoming IRD discussions. Indeed, the 3rd Council of Religion's final decisions specifically underlined that the PRA was open for dialogue and cooperation with followers of other religions, sects and doctrines, and condemned the efforts of any of them to rise above the rest by exploiting certain material, spiritual and psychological

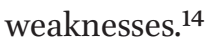

Indeed, the speeches and final decisions of the succeeding Councils, ${ }^{15}$ both during the regular Council of Religion and within the framework of thematic councils such as the Council for EU Accession and the Eurasian Islamic Councils, referred to the same topics, i.e. (1) the need for dialogue with other religions in order to contribute to the world peace, and (2) the misinterpretation of dialogue as an agent for dissolving one religion into another by using it as a propaganda tool for dissemination of a given religion. Both topics constituted the general framework of the PRA's official attitude towards IRD. ${ }^{16}$

The official letter issued by the Foreign Affairs Department of the PRA in 2004, argued that the PRA was criticized for allowing the IRD activities. Although the PRA responded to this criticism with its sloganized motto "Dinler Arası Barış Olmadan Dünya Barışı Bir Hayaldir [World peace without peace among religions is an illusion]" and declared that finding solutions to the contemporary issues of humankind would not harm the main principles of Islam and the doctrine of tawhid [unity], apparently it fell short of countering these criticisms which were meanwhile intensified. ${ }^{17}$

One of the noteworthy developments in this period was the PRA's institutionalization endeavour in the field of IRD. The final decisions of the Second Council of Religion in 1998 had already heralded an important development: establishing a general secretariat for interreligious dialogue under the PRA's roof. A research and documentation centre for world religions was also

\footnotetext{
14 PRA, III. Din Şûrası Kararları, p. 1010.

15 The minutes and final declarations of the Councils are available at the PRA's official website and https://avrasyaislamsurasi.diyanet.gov.tr/en-US/ (retrieved September 19, 2019).

16 The letter was issued by the Foreign Affairs Department of the PRA in response to a question by a religious functionary regarding IRD. Dere, Diyalog Taviz Değildir, pp. 167-172.

17 Uçar, Dinler Arası Diyalog Çıkmazı, p. 6 o.
} 
envisaged as a unit affiliated to this secretariat. ${ }^{18}$ The idea was elaborated at the PRA's International Council for European Union in 2000 through its 16th article by explaining the structure of the Secretariat as a large unit comprising six different sub-departments, namely Relations with Religious Communities in the EU Countries Department, Academic Advisory Board, Relations with Religious Communities in other Christian Countries Department, Relations with Jews Department, Archive and Documentation Centre, Relations with Far East Religions Department. ${ }^{19}$

Although the envisaged Secretariat could not be established, PRA opened a Directory for Interreligious Dialogue affiliated to its Foreign Affairs Department in 1999. The Directory's main areas of responsibility were classified under four categories according to its official directive in $1999:{ }^{20}$ monitoring, participating, analysing and reporting the information about living world religions as well as IRD discussions around the world. However, it is striking that "observing the threatening or separatist acts as well as missionary and assimilative activities" against the Turkish citizens was also included in the responsibilities of the Directory. That also showed that while endorsing IRD, PRA preserved its cautious approach towards any threat to Islam which might be presented under the IRD cover.

In 2009, the Directory underwent an extensive modification. Accordingly, it was transformed into Interreligious Relations Department without any change in its official status and remained under the Department of Foreign Affairs. ${ }^{21}$ The new tasks of the department, which were relatively softened in comparison to the previous ones, concentrated on the practical outcomes such as establishing relations and organizing events for promoting the culture of peace and tolerance etc. in addition to its permanent task of monitoring. The missionary activities were excluded from the requested observation list; instead, acts of religious exploitation and proselytism as well as discrimination against the Turkish citizens were asked to be evaluated. Finally, the department was abolished in the amendment of 2019 and most of its responsibilities were taken over by the Directory of Social and Culture-Oriented Religious Services Abroad. This recently established directory has concentrated more on the social and cultural tasks offered for the religious affairs of Turkish citizens who live abroad. However, the monitoring tasks of the previous interreligious relations department continued to be a part of its responsibilities.

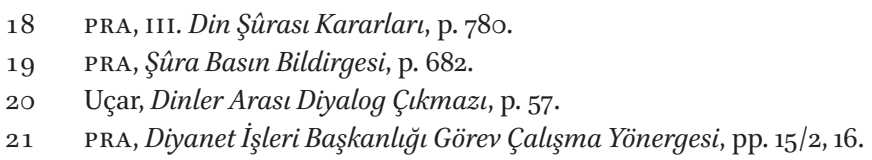


Apart from the official councils, the PRA also maintained its social impactoriented approach in the meetings which it organized or contributed to their organization. Such are Religions in the Faith and Tolerance Age meeting in Tarsus in 2000 and 1st Aleppo Meeting of Civilizations in 2005 to mention but a few. Both meetings embraced understanding of tolerance towards different religions and cultures. While the first was striving for discussing and finding ways to conduct cooperation between them while enabling them to preserve their own differences, the second one was aiming to create a cultural platform to strengthen the peace, brotherhood and tolerance between different religions.

\section{Increasing Numbers of IRD Meetings}

While PRA was much more concentrated on the institutional aspects of IRD and its social impact, the topic became popular among the circles outside PRA owing to its theological and political repercussions. Theology faculties, local religious groups and NGOS, and even local authorities organized many comprehensive meetings between the 199os and 20oos. Although it is difficult to assert that all meetings met the same level of academic standards, many novel concepts such as Abrahamic religions, tearuf [knowing each other], living together and tolerance were introduced into the respective literature as a result.

One of the early IRD meetings in this category was the outcome of the agreement signed between Ankara University and Gregorian University in 1986. Holding the IRD meeting in Rome (1989) on the topic of cooperation between Muslim and Christian theological education, the parties discussed the contemporary theoretical and methodological challenges that theology education encounter. ${ }^{22}$ The Ankara colloquium in 1990, on the other hand, revolved around the conceptual analysis of tolerance, a term which was frequently used as a replacement for IRD. Although the meeting was held at an early stage of IRD discussions in Turkey, it requires attention for two reasons at least. First, the papers presented in the colloquium covered a wide range of topics including the historical, sociological, and most importantly, theological framework of the term; second, not only academics in the field of religious studies but also theologians took part in the meeting. ${ }^{23}$ That meant that theological aspects of IRD also became a highlighted topic in IRD discussions, in contrast to the endeavour which was made by the PRA to focus on the social aspects of IRD.

22 Bilgin, Roma'da İlahiyat Eğitiminde İşbirliği Semineri, pp. 233-239.

23 See Proceedings of the colloquium, Religions, Cultures and Tolerance. 
In a couple of years, another academic meeting gave the signals that the theological aspects of the term had gained more ground and coverage in the academia. Among those is Christian and Muslim Relations in the Present Century meeting, ${ }^{24}$ which was held in 1992 by ISAV, one of the leading researchfocused NGOS with religious orientation. However, one of the noteworthy contributions that the meeting brought to the IRD discussions was the emergence of the negative approaches to IRD long before the apprehensive statements of PRA on the proliferation of missionary activities. The paper, ${ }^{25}$ Küçük, a known Turkish historian of religion, presented at the meeting, played a leading role in planting the association between the IRD activities and missionary acts.

The International Congress on Tolerance, which was held in cooperation between the Ministry of Culture and Akdeniz University in Antalya in $1995,{ }^{26}$ and also the Symposium on Intercultural Dialogue, held by Istanbul Metropolitan Municipality in $1998,{ }^{27}$ among others, can be considered as follow-up meetings which concentrated on the long history of Muslim-non-Muslim relations in Turkish culture and the importance of participating in IRD activities.

In the 2ooos, one of the major academic events, considered to be one of the milestones for IRD, was organized by Marmara University in cooperation with Gregorian University between 2003 and 2007. Using the motto of "Karşıllklı saygı için birbirimizi tanımak [Knowing each other for a mutual respect]", the series was explained as a response to the need for obtaining accurate information about religions as well as eliminating their misrepresentations of them. Particularly in the period when Turkey entered the EU accession negotiations and misjudgements regarding Islam became widespread in the West, IRD was seen as the best option for correcting those opinions. ${ }^{28}$ In order to facilitate exchanging information between religions, the themes of the series were selected from the common key concepts between Islam and Christianity such as the Word of God, Jesus, Salvation, Modernism etc. The meetings, particularly those organized by the Universities, followed the same trend. From them, two are worthy of mentioning, the one at Sivas Cumhuriyet University in 2002, and at Çorum Hitit University in 2008.

The importance of the Symposium on Dialogue for Peace, organized by Sivas Cumhuriyet University's Faculty of Theology, lied in the fact that many religious leaders from Jewish, Indian, Armenian, Syriac, Roman and Muslim

\footnotetext{
24 Collective, Asrımızda Müslüman Hıristiyan Münasebetleri.

25 Küçük, Müslüman-Hıristiyan Diyaloğuna Genel Bir Bakış, pp. 45-59.

26 BİLKav, Uluslararası Hoşgörü Kongresi.

27 Collective, Kültürlerarası Diyalog Sempozyumu.

28 Taşpınar, Takdim, p. 7 .
} 
communities among others participated in the meeting and presented their opinions on the dialogue for bringing peace to their communities and also to the world. ${ }^{29}$ However, it was the Çorum Hitit University's The Contribution of Religions to Living Together Symposium that also signalled a paradigm shift in the Turkish IRD discussions by focusing on the culture of living together and covering mainly the topics related to the Ottoman experience of peaceful coexistence. $^{30}$

\section{$5 \quad$ Challenges to Paradigm Shift}

The early 20oos introduced new challenges as well as new concepts in the Turkish IRD discussions. The following challenges not only triggered a paradigm shift in IRD discussions in Turkey but also caused a certain decline in the interest towards IRD in the academic circles. Among them are the association between the term and the missionary activities, the politicization of the term and its replacement by living together/coexistence to mention only three.

While the popularity of IRD was increasing in the late gos, the term also raised certain concern, as previously noted. One of the frequently mentioned concerns was the disposability of the prevalence of dialogue activities for the purpose of disseminating the Christian message. The special issue of Islamiyat journal - one of the popular academic reviews at the time -, issued in 2002, was dedicated to the association between IRD and missionary activities. The authors of the Mission and Dialogue issue elaborated on different aspects of the association between the terms, including Christian theology, and global challenges. ${ }^{31}$ The special issue of Türk Yurdu in 2005 followed the same approach and concentrated directly on the contemporary dialogue activities as facilitators of the missionary acts. ${ }^{32}$ Soon, these works were transformed into one of the main trends in the IRD discussions which will be discussed in the conclusion.

Another concern regarding IRD was the politicization of the term. Being among the most substantial challenges that IRD encountered in Turkey, the topic faced an extreme decline in terms of its reputation. In parallel with the increasing popularity of IRD, certain religious groups and NGOS started to play

29 Gökbel/Yücel/Işkın, Barış İ̧̧in Diyalog Uluslararası Sempozyum Bildirileri.

30 Evkuran/Cengil/Korukcu/Yavuz/Akyol/Ünlüer, Birlikte Yaşama Kültürü ve Hoşgörü.

31 Aydın, Dinler Arası Diyalog Yeni Bir Misyon Yöntemi mi? pp. 17-48; Gündüz, Dinin Siyasallaşması ve Hıristiyan Misyonu, pp. 49-72.

32 Küçük, Dinler Arası Diyaloğun 'Diğer Yüzü' Üzerine; Öktem, Misyonerlik Olayında İslâm Kazançlı Çıkacaktır; Özemre, Dinlerarası Diyalog ve Misyonerlik. 
a leading role in the late 199os. In particular, Gülen movement [F Eтö], and its satellite institutions took the lead in organizing IRD meetings and producing publications on the matter. Using the term as part of its religious marketing at international level, FETÖ presented itself as an agent of moderate Islam and used IRD as a tool of its expansion in the West. Its efforts to bring a syncretic theological explanation for dialogue generated a growing opposition to the movement. ${ }^{33}$ The recent failed coup on July 15, 2016, which has been associated with the members of FETÖ, showed the extent of the movement's politicization. On the other hand, the movement's IRD activities are severely criticized for being instrumental to spoiling the main principles of Islam as part of its political aspirations.

The third, perhaps not last, challenge occurred in the theoretical basis of the term. Although the PRA had highlighted the social aspects of IRD from the beginning of its involvement in the discussions, the circles outside PRA were mostly concentrated on the theological aspects. At the beginning of 200os, the term living together and less frequently coexistence began to appear first as an associated term and then as a replacement for IRD. Slowly the themes of the symposiums began to transform. In the end, with the visible decline in the popularity of IRD, mainly due to its political connotations, living together became the main reference point in the academic meetings. Two of the early meetings, held in Sivas and Corum respectively, were previously mentioned. The recent meetings, Konya Muftiate's Symposium on Ethics of Living Together with Other Faiths and Culture in $2015^{34}$ and Timav's Symposium on Civilization and Culture of Living Together in $2017,{ }^{35}$ clearly showed that the academic trends had completely turned in favour of living together although the contents are strangely addressing similar topics such as relations between Christians and Muslims, historical background of coexistence in Islamic culture, projections for future cooperation between religions etc.

\section{$6 \quad$ Main Trends in Interreligious Dialogue Discussions in Turkey}

As can be expected, Turkish academics vary in their conceptualization of IRD according to their intellectual and religious developments. However, a quick analysis of literature indicates the existence of common trends among them. These trends, which can be generally classified under the following three titles:

33 PRA, Dini İstismar Hareketi FETÖ/PDY Olağanüstü Din Şûrası Kararları, p. 31.

34 Konya Muftiate, Farklı İnanç ve Kültürlerle Bir Arada Yaşama Ahlâkı.

35 тімav, Medeniyet ve Birlikte Yaşama Kültürü. 
supportive, opposite and cautious ${ }^{36}$ play a key role in comprehending the evolution of IRD discourse in Turkey. However, delving deeper into the related works shows that the trends among the scholars are more content-oriented rather than explaining their position regarding IRD.

IRD as a necessity for social welfare: As was previously seen in the official attitude of PRA towards IRD, many scholars believe that IRD should be promoted because humankind is suffering many conflicts and deficiencies. A mutual understanding between religions might endow them with the power to make the right solutions in their fight against those issues. Some scholars find their motive in Quranic verses (e.g. 49:13), which depict the world as a multicultural community where people have their own faiths in different religions. One of the most striking aspects of such an approach is that some authors furthered their assertions to the point that although it is believed that the Vatican's conceptualization of the term of IRD dates from the Second Vatican Council at the earliest, it was Islam that had actually realized such an interaction between religions as early as the 7 th century. ${ }^{37}$

IRD as an instrument for religious propaganda: A second trend, which holds an opposite stand, sees IRD activities as an effective tool for contributing to the missionary activities. Although missionaries have lost power since the rise of nation states, they have adopted new tools in their response to the challenges of globalization; IRD is among those. This view, which is defended mostly by the scholars with a straight nationalist background, asserts that religions can be neither compatible nor comparable with each other within the limits of theology. Moreover, the concepts such as common father of the religions, garden of religions were fabricated for propagating Christianity and disrupting national and religious unity. ${ }^{38}$

IRD as a part of dialogic relation: Although the theological bases of IRD have always been under debate, some academics preferred to endeavour on constructing a self-sustained theory within the limits of Islamic teachings. Offering a critical reading, such a theory emerged as a reaction to the deficiencies in the previous conceptualization of IRD. Moreover, it was the institutional aspect that they criticized most of all. Therefore, the third trend suggests that the

${ }_{3} 6$ Battal, Türkiye'deki Dinlerarası Diyalog Çalışmaları; Yiğitoğlu, Türkiye'de II. Vatikan Sonrası Müslüman-Hristiyan İlişkileri.

37 Mehmet Aydın, Türk Toplumunda Dini Hoşgörünün Temelleri, pp. 59-69; Aydın, Hz. Muhammed (AS), pp. 81-94; Aydüz, Tarih Boyunca Dinlerarası Diyalog; Karaman, Dinlerarası Diyalog Nedir?.

38 Aydın, Hz. Muhammed (As); Aydın, Türk Toplumunda Dini Hoşgörünün Temelleri; Aydüz, Tarih Boyunca Dinlerarası Diyalog. 
dialogue could only be achieved among the believers of faith, not between the religions. They also recognize the necessity for such a dialogic relation for the sake of maintaining peace and security in the world. ${ }^{39}$

These three trends fell short of explaining all aspects of the IRD discussions in Turkey; however, they summarize the evolution of the IRD discussions in Turkey to some extent. Since the 201OS IRD has been slowly losing its popularity among the academics; however, it was the politicization of the term by religious-political groups that raised concerns and triggered a paradigm shift towards the concept of living together/coexistence. Although they seem similar on the surface, the first reflect mostly the institutional connections while the latter feature the relations between the individuals.

\section{7}

\section{Conclusion}

Although the term of IRD was first introduced to the Turkish academia immediately after the Second Vatican Council, in parallel with its international acknowledgement, only a very limited number of writings referred to the term in the beginning. However, the late 199os signalled an increasing popularity of the term within the academic circles. Apart from the wide range of academic meetings held in this period, a boom was witnessed in available sources quantitatively and qualitatively.

An analysis of the recent literature shows that there are three trends which became predominant among the scholars. These trends can be named as IRD (1) as a necessity for social welfare, (2) as an instrument for religious propaganda, (3) as a part of dialogic relation. Although such a classification indicates a certain content-orientation, it also coincides with the historical evolution of the IRD in Turkey.

Being part of the nexus between politics and theology, as the presented research shows, the topic of interreligious dialogue gradually attracted politically motivated religious organizations. Finally, it became a label for selfrepresentation of several religious groups. Among them Gülen Movement [FETÖ], which has been associated with a failed coup attempt on July 15, 2016, assumed an active role in leading the IRD in Turkey for a long period. Politicization of the term created a certain degree of ambiguity and confusion about the term. As a result, the IRD lost its popularity, at least among the academic circles. 


\section{Biographies}

Ayşe Zişan Furat, MA, PhD, is Associate Professor in Religious Education at the Faculty of Theology, Istanbul University, Turkey. She researches and publishes in the areas of history of education policies in conflict zones, intercultural educational settings, intercultural dialogue, and development of religious identities. She lectures religious education, history of Islamic sciences, and late Ottoman education policies. She has participated in many academic projects and conducted research in Germany, Bosnia and Herzegovina and Lebanon. She is also the author of two books Development of Identity in Islamic Communities and Religious Education and Muslim Religious Education under a non-Muslim Government: Austro Hungarian Bosnia.

Website profile: https://avesis.istanbul.edu.tr/zisanfurat

E-mail address: zisanfurat@istanbul.edu.tr

Hamit Er, MA, PhD, is the chairman of Religious Education Department at the Faculty of Theology, Istanbul University, Turkey. His research concentrates on intercultural educational studies, history of education, Turkish educational policy. He was the editor-in-chief of the Journal "Intercultural and Religious Studies [JIRs]". He published many books and articles in Turkish, English and Japanese. He lectures religious education, contemporary issues of religious education and late Ottoman education policies. He has participated in many academic projects in Holland, Belgium, and Japan.

Website profile: http://aves.istanbul.edu.tr/hamit.er/

E-mail address: hamit.er@istabul.edu.tr

\section{Bibliography}

Alıcl, Mehmet: Understanding "the Other": Attitudes towards Interreligious Dialogue in Turkey, in: İstanbul Üniversitesi İlahiyat Fakültesi Dergisi, no. 17(2008), pp. 237-251.

Alıcl, Mustafa: Müşterek Kelimeler ve Aykırı Oluşlar: Al-i İmran 64. Ayeti ve MüslümanHıristiyan Diyalog Sürecine Pratik Bir Bakış [Common Words and Contrary Beings: 64th Verse of Al-i Imran and a Practical Approach to Muslim-Christian Dialogue], in: Köprü 93 (2006), pp. 23-44.

Alıcı, Mustafa: Kitab-ı Mukaddes ve Kur'an-ı Kerim Işı̆̆ında İslam-Hristiyan Diyaloğu

[Muslim Christian Dialogue in the Light of the Holy Book and Quran]. Marmara University, Unpublished Dissertation, İstanbul, 2001. 
Anık, Mehmet: Çokkültürcülük ve Osmanlı Devleti [Multiculturality and Ottoman State], in: Selçuk Üniversitesi Edebiyat Fakültesi Dergisi, no. 27 (1/2012), pp. 117-13o. Aydın, Ali Arslan: İslâm-Hristiyan Diyaloğu ve İslâmın Zaferi [Dialogue between Islam and Christianity, and the Victory of Islam]. Ankara: İslama Çağn Cemiyeti Yayınları, 1984.

Aydın, Mahmut: Dinler Arası Diyalog Yeni Bir Misyon Yöntemi mi? - Kurumsal ve Bireysel Diyalog Faaliyetleri Üzerine Bir Değerlendirme [Is Interreligious Dialogue a New Method of Mission? An Evaluation of the Institutional and Individual Dialogue Activities], in: islâmiyât 5 (3/2002), pp. 17-48.

Aydın, Mahmut: Müslüman-Hıristiyan Diyaloğunun Geleceği [Future of MuslimChristian Dialogue], in: II. Din Şûrast: Tebliğ ve Müzakereleri, Vol. 2. Ankara: Diyanet İşleri Başkanlığı, 2003, pp. 96-105.

Aydın, Mehmet: Hz. Muhammed (AS) Devrinde Müslüman-Hristiyan Münasebetlerine Bir Bakış [An Overview on Muslim-Christian Relations in Muhammed's (PBuH) Period], in: Asrımızda Hıristiyan-Müslüman Münasebetleri. İstanbul: Ensar Neşriyat, 1993, pp. 81-94.

Aydın, Mehmet: Türk Toplumunda Dini Hoşgörünün Temelleri [Fundamentals of Religius Tolerance in Turkish Society], in: Kültürlerarası Diyalog Sempozyumu. İstanbul: İstanbul Büyükşehir Belediyesi, 1998, pp. 59-69.

Aydüz, Davut: Tarih Boyunca Dinlerarası Diyalog [Interreligious Dialogue throughout History]. İstanbul: Işık Yayınları, 2004.

Battal, Emine: Türkiye'deki Dinlerarası Diyalog Çalışmaları. Ondokuzmayıs University, Unpublished MA Thesis, Samsun, 2008.

Bilgin, Beyza: Roma'da İlahiyat Eğitiminde İşbirliği Semineri [Seminar on the Cooperation in Theology Education in Rome], in: Ankara Üniversitesi Illahiyat Fakültesi Dergisi 32 (1/1991), pp. 233-239.

BİLKAV: Uluslararası Hoşgörü Kongresi [The International Congress on Tolerance]. Ankara: Bilimsel ve Kültürel Araştırmalar Vakfi, 1995.

Collective: Asrımızda Müslüman Hıristiyan Münasebetleri [Christian and Muslim Relations in the Present Century]. İstanbul: İslami Araştırmalar Vakfi, 1993.

Collective: Kültürlerarası Diyalog Sempozyumu [Symposium on Intercultural Dialogue]. İstanbul: İstanbul Büyükşehir Belediyesi, 1998.

Dere, Ali: Diyalog Taviz Değildir [Dialogue is not a Compromise], in: Hayreddin Karaman/Ömer Faruk Harman/Faruk Tuncer (eds.): Polemik Değil Diyalog edited by Hayreddin Karaman/Ömer Faruk Harman/Faruk Tuncer. İstanbul: Ufuk, 20o6, pp. 167-172.

Diyanet İşleri Başkanlığı [Presidency of Religious Affairs]: Dini İstismar Hareketi FETÖ/PDY Olağanüstü Din Şûrası Kararları [A Movement of Religious Exploitation FETO/PDY Decisions of Extraordinary Council of Religion]. Ankara: Diyanet İşleri Başkanlı̆̆ı, 2016. 
Diyanet İşleri Başkanlığı [Presidency of Religious Affairs]: Diyanet İşleri Başkanlığı Görev Çalışma Yönergesi [Working Rules of the Presidency of Religious Affairs] (abrogated) (2002).

Diyanet İşleri Başkanlığı [Presidency of Religious Affairs]: I. Avrasya İslâm Şûrası Teşkilatı Toplantısı Sonuç Bildirisi (25 Ekim 1995) [Final Declaration of the First Eurasian Islamic Council (October 25, 1995). Official Website. Eurasian Islamic Council, 1995. https://avrasyaislamsurasi.diyanet.gov.tr/tr-TR/Declaration/Detail/1 (date of last access: 15.09.2020).

Diyanet İşleri Başkanlığı [Presidency of Religious Affairs]: II. Avrasya İslâm Şûrası Teşkilatı Toplantısı Sonuç Bildirisi (25 Ekim 1996 / İstanbul) [Final Declaration of the Second Eurasian Islamic Council (October 25, 1996). Official Website. Eurasian Islamic Council, 1996, https://avrasyaislamsurasi.diyanet.gov.tr/tr-TR/Declaration/ Detail/2 (date of last access: 15.09.2020).

Diyanet İşleri Başkanlığı [Presidency of Religious Affairs]: II. Din Şûrası Tebliğ ve Müzakereleri (23-27 Kasım 1998) [Proceedings of the Second Council of Religion (November 23-27, 1998)], 2 vols. Ankara: Diyanet İşleri Başkanlığı Yayınları, 2003 .

Diyanet İşleri Başkanlığı [Presidency of Religious Affairs]: III. Din Şûrası Kararları [Decisions of the Third Council of Religion]. In III. Din Şûrası Tebliğ ve Müzakereleri (20-24 Eylül 2004/Ankara), 1008-1014. İlmi Eserler 642. Ankara: Diyanet İşleri Başkanlığı Yayınları, 2005.

Diyanet İşleri Başkanlığı [Presidency of Religious Affairs]: IV. Avrasya İslâm Şûrası Teşkilatı Toplantısı Sonuç Bildirisi (28 Temmuz 2000) [Final Declaration of the Fourth Eurasian Islamic Council (July 25, 2000). Official Website. Eurasian Islamic Council, 200o, https://avrasyaislamsurasi.diyanet.gov.tr/tr-TR/Declaration/Detail/4 (date of last access: 15.09.2010).

Diyanet İşleri Başkanlığı [Presidency of Religious Affairs]: Şûra Basın Bildirgesi [Press Release of the Council], in: Uluslararası Avrupa Birliğ i Şûrası Tebliğ ve Müzakereleri (3-7 Mayıs 200o), Vol. 2. Ankara: Diyanet İşleri Başkanlığı, 20oo, pp. 679-688.

Diyanet İşleri Başkanlığı [Presidency of Religious Affairs]: v. Avrasya İslâm Şûrası Teşkilatı Toplantısı Sonuç Bildirisi (19 Nisan 2002) [Final Declaration of the Fifth Eurasian Islamic Council (October 25, 1995). Official Website. Eurasian Islamic Council, 2002, https://avrasyaislamsurasi.diyanet.gov.tr/tr-TR/Declaration/Detail/5 (date of last access: 15.09.2020).

Evkuran, Mehmet/Cengil, Muammer/Korukcu, Adem/Yavuz, Sefer/Akyol, Aygün/ Ünlüer, Ceyhun (eds.): Birlikte Yaşama Kültürü ve Hoşgörü [The Contribution of Religions to Living Together]. Çorum: Hitit Üniversitesi İlahiyat Fakültesi, 2010.

Gökbel, Ahmet/Yücel, Abubekir Sıddık/Işkın, Gökhan Sebati (eds.): Barış İçin Diyalog Uluslararası Sempozyum Bildirileri [Proceedings of the International Symposium on Dialogue for Peace]. Sivas: Cumhuriyet Üniversitesi Basımevi, 2003. 
Gölcük, Şerafettin: Dinler Arası Diyalogla İlgili Başkanlık Görüşü [Presidential Opinion on Interreligious Dialogue], in: II. Din Şûrası: Tebliğ ve Müzakereleri, Vol. 2. Ankara: Diyanet İşleri Başkanlığı, 2003, pp. 3-6.

Gündüz, Şinasi: Dinin Siyasallaşması ve Hıristiyan Misyonu [Politicization of Religion and Christian Mission], in: islâmiyât 5, no. 3 (2002): pp. 49-72.

Gündüz, Şinasi: Küresel Sorunlar ve Din [Global Problems and Religion]. Ankara: Ankara Okulu, 2005.

Karaman, Hayreddin: Dinlerarası Diyalog Nedir? [What is Interreligious Dialogue]. İstanbul: Ufuk Kitapları, 2005.

Konya Muftiate: Farklı İnanç ve Kültürlerle Bir Arada Yaşama Ahlâkı [Symposium on Ethics of Living Together with Other Faiths and Culture]. Konya: Konya IIl Müftülüğü Kültür Yayınları, 2015.

Küçük, Abdurrahman: Dinler Arası Diyaloğa Niçin İhtiyaç Vardır [Why there is a Need for Interreligious Dialogue], in: II. Din Şûrası: Tebliğ ve Müzakereleri, Vol. 2. Ankara: Diyanet İşleri Başkanlığı, 2003, pp. 158-173.

Küçük, Abdurrahman: Dinler Arası Diyaloğun 'Diğer Yüzü' Üzerine [On 'the Other Side' of Interreligious Dialogue]. Türk Yurdu, 2005.

Küçük, Abdurrahman: Müslüman-Hıristiyan Diyaloğuna Genel Bir Bakış [A General Outlook on Muslim-Christian Dialogue], in: Asrımızda Hıristiyan-Müslüman Münasebetleri. İstanbul: Ensar Neşriyat, 1993, pp. 45-59.

Öktem, Niyazi: Misyonerlik Olayında İslâm Kazançlı Çıkacaktır [Islam will Benefit from the Missionary Case]. Türk Yurdu, 2005.

Özemre, Ahmed Yüksel: Dinlerarası Diyalog ve Misyonerlik [Interreligious Dialogue and Missionary Activities]. Türk Yurdu, 2005.

Proceedings of the colloquium, Religions, Cultures and Tolerance. Past and Present. November 1-2, 199o. Ankara Üniversitesi Rektörlüğü Yayınları, 1991.

Sarıkçıŏlu, Ekrem: İbrahim Dinine Güncel Yaklaşım [A Contemporary Approach towards Abrahamic Religion], in: II. Din Şûrası: Tebliğ ve Müzakereleri, Vol. 2. Ankara: Diyanet İşleri Başkanlığı Yayınları, 2003, pp. 137-142.

Swiss Metadatabase of Religious Affiliation in Europe / SMRE (ed.): Countries and Regions: Turkey. Lucerne 2018, https://www.smre-data.ch/en/data_exploring/region_cockpit\#/mode/dataset_comparison/region/TUR/period/2010/presentation/ bar (date of last access: 4.8.2020).

Taşpınar, İsmail: Takdim [Introduction], in: İslam ve Hıristiyanlık'ta Kurtuluş Uluslararası Müslüman - Hıristiyan Diyaloğu Sempozyumu. İstanbul: Saint Ettienne, 2007, pp. 7 et seq.

тimav: Medeniyet ve Birlikte Yaşama Kültürü [Civilization and Culture of Living Together]. Konya: тімAV, 2017. 
Uçar, Ramazan: Dinler Arası Diyalog Çıkmazı: Din Görevlileri Üzerine Sosyolojik Bir Araştırma [Interreligious Dialogue Deadlock: A Sociological Research on Religious Functionaries]. Istanbul: Kelam Yayınları, 2007.

Uludağ, Süleyman: Sosyal Barışı Sağlamada Dinin ve Din Adamının Rolü [The Role of Religion and Religious Man in Establishing Social Peace], in: II. Din Şûrası: Tebliğ ve Müzakereleri, Vol. 2. Ankara: Dї B, 2003, pp. 151-157.

Yiğitoğlu, Mustafa: Türkiye'de II. Vatikan Sonrası Müslüman-Hristiyan İlişkileri. Marmara Üniversitesi, 2006.

Yılmaz, Mehmet Nuri:Diyanet İşleri Başkanı Mehmet Nuri Yılmaz'ın Kapanış Konuşması [Closing Remarks of Mehmet Nuri Yılmaz, the Head of the Presidency of Religious Affairs], in: II. Din Şûrası: Tebliğ ve Müzakereleri, Vol. 2. Ankara: Diyanet İşleri Başkanlığı Yayınları, 2003, pp. 765-774. 